\title{
THE IDEA OF POST-WAR AMERICA IN SELECTED NOVELS BY STEINBECK AND DOS PASSOS
}

\section{Mr. Digvijaysinh G. Gohil}

\begin{abstract}
:
This article attempts to study the idea of the 'Other' according to John Dos Passos (1896-1970) and John Steinbeck (1902-1968). The researcher has analyzed the position of the two authors towardsmajor post-war issues. Throughout the article, the researcher highlights numerous social, racial, gender, political, and economic issues that arose as a result of the aftermath of the First World War. The appropriation of the New Historicist theory enablesus to make a historical and literary diagnosis of John Dos Passosand Steinbeck's fiction. The researcher has endeavored to demonstrate that both Dos Passos and Steinbeck share the same idea, position, and vision towards a fragmented, class-based, 'white supremacist' and capitalist post-war America.

The following novels have been analyzed from the perspective of racial and gender discrimination for the purpose of the research: Steinbeck's Tortilla Flat (1935), Of Mice and Men (1937), The Grapes of Wrath (1939); and Dos Passos' trilogy U.S.A (1938).This paper also explores another post-war theme - the proletariat vs. big businessstruggle.The proletariat theme is an influential part of Dos Passos' fictional trilogy and Steinbeck's epic novel The Grapes of Wrath. The researcher endeavours to demonstrate that the two authors share the idea that postwar America is composed of two-nations - 'proletariat' and the privileged.
\end{abstract}

Key words:Post-war America,the Great Depression,economic crisis, socialism, radicalism, socio-economic conditions, migrant workers, psychological and anthropological perspectives

\section{INRODUCTION:}

The purpose of this article is to study the idea of the other in post-war American fiction according to John Dos Passos's trilogy U.S.A and John Steinbeck's novels TortillaFlat (1935), Of Mice and Men (1937), and The Grapes of Wrath (1939). Indeed, the aftermath of the Great War knew several upheavals and agitations in America in terms of race, politics, and society. Anti-foreign attitudes attained their climax in the years just after the Great War. Spokesmen for ' 100 percent Americanism' influenced the enactment of anti-immigration laws. In addition, the revival of the $\mathrm{Ku}$ Klux Klan triggered a racist atmosphere all over the country. Moreover, the outburst of the Red Scare also coincided with the post-war era.

Communists, radicals, anarchists, and labor figures were pursued and condemned throughout the nation. The famous Sacco and Vanzetti's trial illustrated this fear towards the 'Reds'. The two 
Italian-born anarchists were condemned for the murder of F.A.Parmenter, i.e, who was a paymaster of a shoe factory, and his guard Alessandro Berardelli.

Sacco and Vanzetti were executed on August 23, 1927. It is worth mentioning that John Dos Passos, among other intellectuals, participated in the several mobilizations so as to free Sacco and Vanzetti. He wrote a pamphlet entitled Facing the Chair (1927) to support the two accused. Their execution constituted a true 'évenément déclencheur' that urged John Dos Passos to write his landmark trilogy U.S.A (1938). He referred to Sacco and Vanzetti's 'causecélèbre' in the third sequel of his trilogy that is entitled The Big Money (1936). He wrote after their execution that 'all right we are two nations'. With the publication of the trilogy, he became the 'artistic and intellectual spokesman for the far left' during the 1930s.

\section{The Great Depression between the Great Wars:}

Another milestone issue during the post-war era in America was the Great Depression. The latter began in 1929 after the Great Crash of Wall Street. It was the longest and most severe depression ever experienced by America. The economic crisis left millions of homeless families and unemployed all over the country.

The depression era also experienced another catastrophe. The latter concerns the 'Dust Bowl' that struck the Great Plains in the early 1930s. Thousands of American families migrated to California in order to find a more decent life. A literary work that summed up the bitterness of the Great Depression and the Dust Bowl was John Steinbeck's The Grapes of Wrath (1939). John Steinbeck as a Californian was a direct witness of the arrival of these migrant workers to California. Therefore, the researcher can say that Dos Passos's and John Steinbeck's works reflected the issues of their era throughout their novels. The two literary figures shared some characteristics. Both of them were foreign descendants, i.e, the grandfather of Dos Passos was a Portuguese and Steinbeck's grandfather was German. In addition, the two authors exercised as journalists, and they borrowed some journalistic and modernist techniques to their fiction. Moreover, they were sympathizers of socialist and left ideas. Furthermore, Dos Passos's U.S.A and Steinbeck's The Grapes of Wrath were collective novels, i.e, their protagonists were groups of people without an individual hero.

Dos Passos's and Steinbeck's novels have been the centre of interest for many critics. Criticism on John Dos Passos's fiction has been carried out under multiple angles. Laura Browder in her book entitled Rousing the Nation: Radicals Culture in Depression America (1998) devotes a long chapter to John Dos Passos. She sustains that Dos Passos is a 'historianof American life' throughout his depiction of America in the trilogy U.S.A (1938). She emphasized that the trilogy's characters range from radicals, Wobblies, and big business figures. Therefore, this 'multi-social' depiction offers to the trilogy a 'socio-cosmopolitan' dimension.

John Trombold (1995) tackles another issue with his study that concerns the impact of the popular songs that are launched throughout the trilogy U.S.A (1938) on a growing revolutionary spirit of the post-war era. Another critic who enlarges the scope of Dos Passos criticism is Joseph Fichtelberg (1988). Indeed, the latter argues that the author's fiction embodies a 'picaresque' element, i.e, the term means 'tale of the road'. According to Joseph Fichtelberg, Dos Passos's characters are somewhat 'desperate' vagabonds. He adds that Dos Passos's protagonists experience solitude, seek a substitute home, and they are savagely beaten and jailed by 'high- 
class' protectors of the society they seek to enter. In this respect, one can refer to the prologue of U.S.A that denotes this 'picaresque' idea in Dos Passos's fiction. The young man must catch the last subway, the streetcar, the bus, run up the gangplanks of all the steamboats, register at all the hotels, work in the cities, answer the wan tads, learn the trades, take up the jobs, line in all the boardinghouses, sleep in all the beds. One bed is not enough, one job is not enough, one life is not enough. At night, head swimming with wants, he walks by himself alone. Several other critics deal with the various ways in which Dos Passos uses historical materials to write fiction. One of these critics is Barry Maine (1985). He emphasizes that Dos Passos's U.S.A is a literary work that stands "somewhere between history and fiction".

For him, Dos Passos chooses the term 'chronicle', i.e, a written record of historical events, in order to combine fact and fiction altogether. This echoes Dos Passos's assumptions "I putsome slice of history back to life". Therefore, Dos Passos combines history and fiction to the contents of U.S.A. The trilogy is composed of factual contents such as: the newspaper clippings, popular songs, and biographies of several American figures. Barry Maine also maintains that Dos Passos borrows the language, form, and structure from the cinema to write his trilogy U.S.A. He explains that "the titles of two of the four narrativesequences "Newsreels" and "Camera Eye" are obvious borrowings from thelanguage of pictures". This denotes the influence of the cinematic genre on Dos Passos's trilogy U.S.A.

\section{The issues in Don Passos and Steinbeck's novels:}

Barry Maine opened another angle within Dos Passos's criticism. He sustains that Steinbeck is in 'literary' debt to Dos Passos. Barry Maine explains that Steinbeck read and admired Dos Passos's work during the 1920s and 1930s. He refers to the use of 'interchapters' in The Grapes of Wrath (1939). For him, the so-called 'interchapters' are inspired by the trilogy U.S.A. In his trilogy, Dos Passos interrupts his fictional narratives with the 'Newsreels' and short biographies of public figures. In the same manner, the interchapters in John Steinbeck's The Grapes of Wrath (1939) interrupt the development of the fiction, so as to highlight the severe and painful socioeconomic conditions that the Joad family must experience. Barry Maine states that the objective of the inter-chapters of The Grapes of Wrath (1939), as in Dos Passos's U.S.A, is to enlarge the dimension of the fiction by exposing a large picture of the American society.

This is a short and succinct review of the most representative critics of Dos Passos's trilogy U.S.A. Concerning John Steinbeck's Tortilla Flat (1935), Of Mice and Men (1937), and The Grapes of Wrath (1939), they have received a considerable bulk of criticism. Philip D. Ortega maintains that John Steinbeck 'caricatures' the image of the 'Chicanos' by presenting them as drunken, lazy, and errant characters. Philip D. Ortega (1996) refers to Steinbeck's assumptions in the novel, when Steinbeck wrote that the 'paisanos' are "clear ofcommercialism, free of the complicated systems of American business".

According to Charles R. Metzger (1995), there is 'essentialism' in Steinbeck's TortillaFlat, because John Steinbeck "does not purport to do more than present one kind of MexicanAmerican, the paisano errant, in one place, Monterey, and at one time, just after World WarI". Moreover, Louis Owens wrote articles entitled 'Reading Steinbeck' published by 'TheCalifornian'. Owens criticizes the treatment of the paisanos in Steinbeck's Tortilla Flat. He maintains that the author "doesn't offer a great deal to multiculturalism. His treatment ofwomen 
Towards Excellence: An Indexed, Refereed \& Peer Reviewed Journal of Higher Education / Mr.

Digvijaysinh Gohil / Page 120-125

and what today would be called people of color leaves a lot to be desired. He was awhite, middle class from Salinas. He was a product of his times".

Charlotte Cook Hadella (1993) sustains that Curley's wife is the main cause of Lennie Small's downfall and that Steinbeck 'makes Curley's wife the instrument of destruction of theland dream. The mythical discourse of the fiction dictates that a woman precipitates the exilefrom paradise". The dream of George and Lennie to possess their 'own' farm is ruined by the devastating charm of Curley's wife. The latter provokes Lennie with her attractive softness without knowing that her provocation is the first step towards her destruction. The novella tells the tragic story of two migrant workers, George Milton and Lennie Small, who endeavor to fulfill their dream, i.e., to own a farm, but the husky and disabled Lennie kills Curley's wife because he is attracted by her softness.

Another critic who has studied John Steinbeck's Of Mice and Men (1937) is Mickael J.Mayer (2009). He maintains that loneliness and isolation are the central themes of the novel. He emphasizes that all the characters of the novel experience loneliness. The 'black stable buck' Crooks, Curley's wife, and Candy are described as being lonely characters without concrete 'inter-social' connections. Nonetheless, Mickael J. Meyer explains that George is in double position towards loneliness, i.e., sometimes he rejects solitude and sometimes he wishes to live alone. Indeed, George often hopes that his bond with Lennie can be broken. George finds that Lennie represents a burden for his actions. Despite George's will to live alone, he is too attached to lennie and he cannot break the bond.

Apart from George's psychological reading, Brian E. Railsback proposes an anthropological analysis of Steinbeck's fiction in his essay On Darwinism; he emphasizes that Steinbeck's The Grapes of Wrath echoes Charles Darwin's theory of evolution. According to him, "in no other book is Steinbeck's dramatization of Darwin's theory more clear; the novelresonates with the naturalist's ideas". This epic novel is the 'sum-total' of Darwinism, i.e, the novel includes the essential elements of evolution: the struggle for survival, existence, and the natural selection's determinism. Brian E.Railsback demonstrates that the migrant workers try to survive by their migration to California. However, the tough and rigid 'natural selection' of California complicates the daily life of the Joad family and the other migrants.

This echoes Darwin's assumptions "In the survival of favored individuals and races, duringthe constantly recurrent struggle for existence, we see a powerful and everacting form ofselection". Under the effect of this natural selection, some characters have a sense of victory. The harsh socio-economic conditions of the 1930s urged Ma Joad and Tom Joad to undermine these difficulties in order to survive.

In addition to the psychological and anthropological perspectives on Steinbeck's TheGrapes of Wrath (1939), Malcolm Cowley (2005) has suggested a sociological reading. His study concentrates on John Steinbeck's sympathy for the migrants and their endeavor to unite themselves against their 'economic' oppressors. According to him, The Grapes of Wrath is classified among the angry books of American literature, it belongs "very high in the categoryof the great angry books like Uncle Tom's Cabin that roused a people to fight againstintolerable wrongs". Fredericc I. Carpenter (2005) tackles the same theme of solidarity. He emphasizes that the Joads move from "I" to "We" in order to escape from chaos. A new Joads's social group is forming, based on the term 'en masse'. 
Towards Excellence: An Indexed, Refereed \& Peer Reviewed Journal of Higher Education / Mr.

Digvijaysinh Gohil / Page 120-125

\section{CONCLUSION:}

To conclude, the above mentioned ideas about John Dos Passos and John Steinbeck, one can notice that many studies have already dealt with their novels. Hitherto, little research has been devoted to their similar vision of post-war America. This article attempted to add a new perspective within the post-war analysis of John Steinbeck and John Dos Passos's respective fictions. Indeed, this article has analyzed the idea of post-war America as it is articulated in Dos Passos's U.S.A and Steinbeck's Of Mice and Men (1937), and The Grapes of Wrath (1939).

\section{REFERENCES:}

Browder, Laura.Rousing the Nation; Radical Culture in Depression America. University of Massachusetts Press,Amherst, 1998.

Carpenter, Frederic. "The Novel and American Transcendentalism" in Harold Bloom, Ed. Bloom's Guides:John Steinbeck's The Grapes of Wrath. Chelsea House Publishers, Philadelphia,2005.

Cowley, Malcolm. "Fight Against Intolerable Wrongs" in Harold Bloom, Ed. Bloom'sGuides:John Steinbeck's The Grapes of Wrath. Chelsea House Publishers, Philadelphia, 2005.

Dos Passos,John.U.S.A(originally published 1938) The Library of America, New York, 1996.

Fichtelberg, Joseph. "The Picaros of John Dos Passos",Twentieth Century Literature. Vol. 34, Number 4, page 435, 1988.

Hayashi,Tetsumaro(Ed.)John Steinbeck: the Years of Greatness-1936-1939. The University of Alabama Press, Tuscaloose, 1993.

Maine,Barry. "U.S.A: Dos Passos and the Rhetoric of History" in South Atlantic Review. Vol. 50, Number.1, page 75, 1985.

Maine. Barry "Steinbeck's Debt to Dos Passos" in Barbara A. Heavilin,Ed. The CriticalResponse to John Steinbeck's The Grapes of Wrath. Greenwood Press, Westport, 2000.

Maine,Barry (Ed.)John Dos Passos: The Critical Heritage. Routledge, London, 2005.

Meier,T.K. “John Dos Passos and Politics" in Contemporary Literature, Vol.23, Number 2, page 263,1982

Meyer. Mickael J. “One is the Loneliest Number: Steinbeck's Paradoxical Attraction and Repulsion to Isolation/ Solitude" in Mickael J. Meyer,Ed. The Essential Criticism of JohnSteinbeck's Of Mice and Men. The Scarecrow Press, Lanham, 2009.

Railsback. Brian E. “On Darwinism” in Harold Bloom, Ed. Bloom's Guides: JohnSteinbeck's

The Grapes of Wrath. Chelsea House Publishers, Philadelphia,2005. 
Towards Excellence: An Indexed, Refereed \& Peer Reviewed Journal of Higher Education / Mr. Digvijaysinh Gohil / Page 120-125

Shillinglaw, Susan. "Steinbeck and Ethnicity,"in Demott Robert,Ed. After the Grapres ofWrath: Essays on John Steinbeck in Honor of Tetsumaro Hayash., Ohio University Press, Ohio, 1995.

Steinbeck,John.Of Mice and Men.OUP, London, 1971.

Trombold, John. "Popular Songs as Revolutionary Culture in John Dos Passos's U.S.A and Other Early Works" in Journal of Modern Literature. Vol.19, Number.2, page 289. 1995.

\section{Digvijaysinh G. Gohil Shree Sahjanand Arts and Commerce College Ahmedabad dgohil75@gmail.com}

